\title{
Belgica's Antarctic Toponymic Legacy
}

\author{
Roger H. Charlier ${ }^{\dagger}$, Marie-Claire P. Chaineux ${ }^{\ddagger}$, Charles W. Finkl ${ }^{\S}$, and Alexandre C. Thys ${ }^{\dagger}$ \\ †rije Universiteit, Brussel \\ Brussels, Belgium \\ rocharli@vub.ac.be \\ Institut Ste Marie \\ Brussels, Belgium \\ ${ }^{5}$ Coastal Education \\ and Research \\ Foundation \\ West Palm Beach \\ Florida
}

\begin{abstract}
${ }^{1}$
CHARLIER, R.H.; CHAINEUX, M.-C.P., FINKL, C.W., and THYS, A.C., 2010. Belgica's Antarctic toponymic legacy. Journal of Coastal Research, 26(6), 1168-1171. West Palm Beach (Florida), ISSN 0749-0208.

It might be argued that this paper does not sensu stricto contribute to "polar science." It, however, rekindles aspects of its history and of that of both oceanography and cartography. Obviously the interest for the polar regions was keen in the 19th century and elicited financial support. The paper may lift anew the veil that has somewhat dimmed the light that should shine on polar science achievements of Belgian explorers and scientists.

Knowledge of the names of geographic features in the Antarctic is probably less widespread, and yet, there are many Belgian names on and near the southernmost continent. Most names were given by the head of the first-ever Antarctic expedition to spend a winter on the southernmost continent. Belgian Royal Navy Lieutenant Adrien de Gerlache de Gomery's expedition in the Antarctic brought back a wealth of scientific information. His trip ended precisely 111 years ago, and has been-literally_carved in stone as the Belgica is indeed one of the 20 oceanographic vessels Prince Albert I of Monaco selected to be represented on the façade of the Musée Océanographique de Monaco.
\end{abstract}

There is no shortage of Belgian toponyms in North America, what with often more than one site named Brussels (Wisconsin), Antwerp (New York et al.), Ghent (Minnesota), Hoboken (New Jersey), Charleroi (Pennsylvania), Namur (Wisconsin), Waterloo (several), Namur (Wisconsin), Louvain (Texas), Luxemburg (Wisconsin), even Belgium (Florida). Some names were anglicized, others kept their "native" spelling. Canada was Nova Belgica to Renaissance Antwerp cartographers Mercator (1512-1594) and Ortelius (1527-1598), and some geographers recall that an island on the Hudson River was Nouvel Avesnes and Nouveau Bruxelles before becoming Nieuw Amsterdam and ultimately New York.

Knowledge of the names of geographic features in the Antarctic is probably less widespread, and yet, many Belgian names were given features on and near the southernmost continent. The Antarctic area where the Belgica expedition named so many geographic features "placed them on the map" (Figures 1-3) is replete with animal life and a photographer's paradise and invites ecology-friendly tourism. Most names were given by the head of the first-ever Antarctic expedition to spend a winter on the southernmost continent. The Norwegian whaler Patria, built for Arctic navigation, was acquired by a young navy lieutenant Adrien de Gerlache de Gomery (Figure 4) who wanted to explore-perhaps to discover-the South Pole. He never did, but was the first to "overwinter" in the Antarctic, and brought back a wealth of scientific information. His famed trip ended precisely 111 years ago, and has been-literally - carved in stone. His ship, the Belgica, is indeed one of the few vessels that Prince Albert I of Monaco selected to be represented on the façade of the Musée

DOI: 10.2112/10A-00005.1 received and accepted in revision 31 March 2010.

(c) Coastal Education \& Research Foundation 2010.
Océanographique de Monaco, which he built, also roughly a century ago, not far from the sovereign's palace. ${ }^{2}$

There are today probably few islands that remain to be discovered, and thus named by the person who first locates it, but such was not the case at the end of the 19thcentury, and de Gerlache and his crew were plying mostly unchartered seas. The Belgica, before ploughing into Antarctic waters, sailed in and about Tierra del Fuego and Graham Land, where several islands were spotted and named. The names can be grouped in two categories: towns and regions, and names of individuals (Table 1).

Cities and one province were honoured. ${ }^{3}$ Antwerp (in French, Anvers; Flemish, Dutch, and German, Antwerpen; Italian, Anversa; Spanish, Ambérès) was first on the list. The ship had been held up there because stevedoring and other services had not been paid for and there was no more money available. Antwerp prominent mecenae dug into their pockets to get the expedition finally on its way. De Gerlache never did forget it and thus was the name of the city that once was the largest in the world, and still a ranking third or fourth harbour in the 19th century world, given to the largest island (Île [d'] Anvers) de Gerlache discovered. Antwerp is also the name of a $>100$ year-old lakeside city in New York State. Palmer Station, Antarctica's only U.S. station north of the Antarctic Circle is on

\footnotetext{
${ }^{1}$ An extended abstract was presented as a paper by the lead author at the International Polar Year congress (IPY) in Oslo in June 2010

${ }^{2}$ Carpine, C. 1968. Les navires océanographiques dont les noms ont été choisis par S.A.S. le Prince Albert $1^{\mathrm{er}}$ pour figurer sur la façade du Musée océanographique de Monaco. Bull. Inst. océanogr. Monaco, $\mathrm{n}^{\circ}$ spécial 2 [Congrès International de l' Histoire de l'Océanographie. 1], pp. 627-638.

${ }^{3}$ In the case of Anvers (Antwerp) there is not unanimity: although most authors lean toward "honouring" the city, some sources hold that it is the province of the same name that was meant.
} 


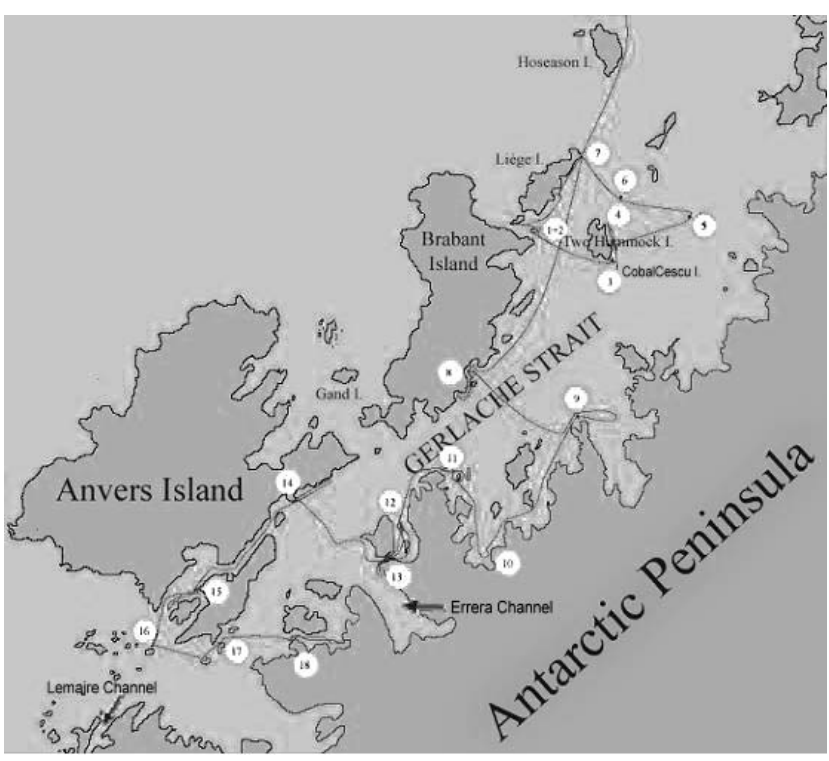

Figure 1. Anvers, Gand, Brabant, Liège islands and de Gerlache [exBelgica] Strait. Travel route of a 2004 sailboat excursion retracing the travel of the Belgica. It is related in a document titled In the Wake of the Belgica. Stops are indicated by numbers superimposed on the map. Euronav, an integrated owner, operator, and manager of ocean-going tankers, is proud to be the sole sponsor of In the Wake of the Belgica expedition. The Belgian Postal Administration, in collaboration with the Greenlandic Post, decided to issue a commemorative postcard using the classic image of the In the Wake of the Belgica expedition (Figure 3). The documentary In the Wake of the Belgica was nominated at the San Fransisco Ocean Film Festival.

Anvers Island. The British Antarctic Survey operated a station for the purpose of survey and geology. Anvers Island was the scene of the protagonist Grim Fiddle's "kingdom" and his later imprisonment in John Calvin Batchelor's novel The Birth of the People's Republic of Antarctica. Fiddle was an adventurer in a

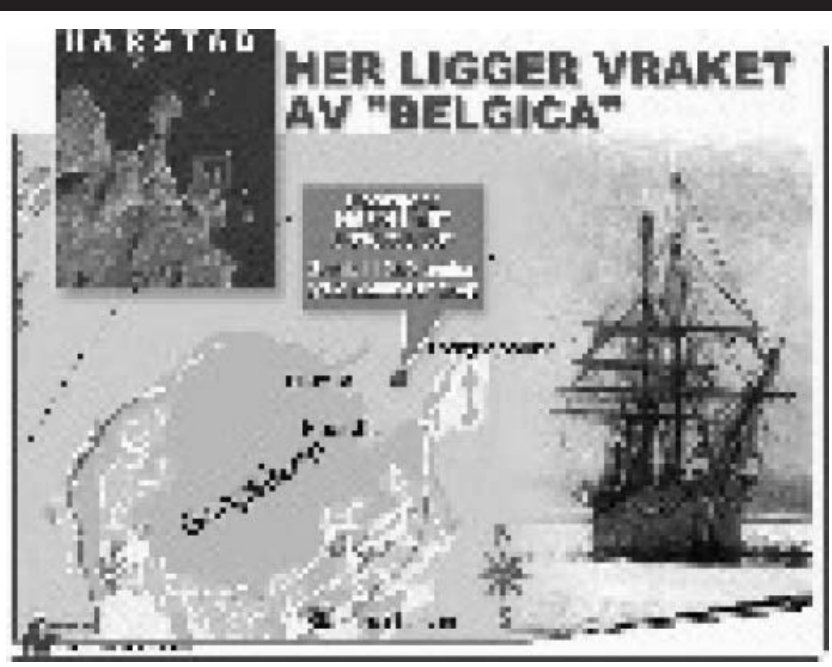

Figure 2. Poster indicating site where the Belgica rests since 1940 some $20 \mathrm{~m}$ below the surface.

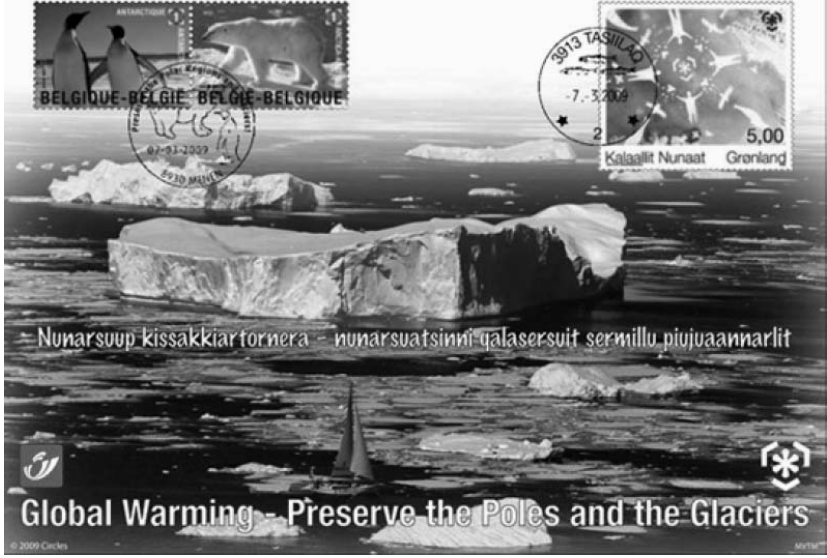

Figure 3. The Belgian and Greenlandic posts' joint commemorative postcard of the In The Wake of the Belgica expedition.

dystopian future world with many references to Norse mythology. The province of Brabant had also provided help to the venture and thus when another island was discovered, it became [de] Brabant Island, probably Île [de] Brabant, since de Gerlache, though Flemish, born in Hasselt-a town in the province of Limburg-was a francophone. Still in the same general area is the Île de Gand, after a Flanders city with a rich historical past; it is known as Gent in Flemish and Ghent in English. This is, incidentally, also the name of a town in Minnesota. The island is the site of a permanent U.S. Antarctic station, but at this writing the United States has not had the urge to change the name or even to anglicize it. Historical weight obliges, probably. Liège is the city where scientific complement member Arctowski studied at the university, becoming and a chemist and a geologist. It was not forgotten in the island-naming frenzy.

Individuals whose names were given to Antarctic islands are equally numerous; first the young sailor who was swept overboard and could not be saved, notwithstanding truly heroïc efforts, got "his" island, thus [Carl] Wiencke Island lies on

\section{de Gerlache \& Belgica in Antarctica}
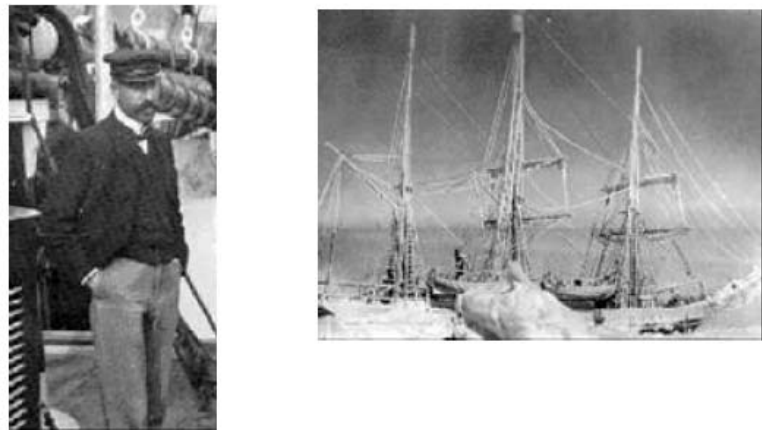

Figure 4. de Gerlache and Belgica in Antarctica. 
Table 1. Belgian toponyms in Antarctica. Except for Wiencke Island, features named by the Belgica Expedition, but those not of Belgian origin are not included.

\begin{tabular}{|c|c|c|c|c|}
\hline \multirow{2}{*}{$\begin{array}{c}\text { Geographical } \\
\text { Feature }\end{array}$} & \multirow{2}{*}{$\begin{array}{l}\text { Name Given } \\
\text { the Feature }\end{array}$} & \multirow{2}{*}{$\begin{array}{l}\text { Source of } \\
\text { Name }\end{array}$} & \multicolumn{2}{|c|}{ Geographical Coordinates } \\
\hline & & & Latitude S & Longitude W \\
\hline I & Anvers & $\mathrm{CP}$ & $64^{\circ} 38^{\prime} 701^{\prime \prime}$ & $63^{\circ} 03^{\prime} 109^{\prime \prime}$ \\
\hline I & Brabant & $\mathrm{P}$ & $64^{\circ} 64^{\prime} 500^{\prime \prime}$ & $62^{\circ} 18^{\prime} 509^{\prime \prime}$ \\
\hline I & Gand & $\mathrm{P}$ & & \\
\hline I & Liège & $\mathrm{CP}$ & $64^{\circ} 02^{\prime}$ & $61^{\circ} 91^{\prime}$ \\
\hline Bay & Flanders & $\mathrm{P}$ & & \\
\hline I & Danco & DInd & $64^{\circ} 44^{\prime}$ & $62^{\circ} 37^{\prime}$ \\
\hline I & Wiencke & DInd & $63^{\circ} 31^{\prime} 226^{\prime \prime}$ & $63^{\circ} 31^{\prime} 226^{\prime \prime}$ \\
\hline $\mathrm{C}$ & Anna & Ind & $64^{\circ} 35^{\prime} 233^{\prime \prime}$ & $62^{\circ} 35^{\prime} 225^{\prime \prime}$ \\
\hline I & Auguste & Ind & $64^{\circ} 03^{\prime} 412^{\prime \prime}$ & $61^{\circ} 36^{\prime} 503^{\prime \prime}$ \\
\hline Cst & Danco & Ind & & \\
\hline Is & Gaston & Ind & $64^{\circ} 29^{\prime} 408^{\prime \prime}$ & $61^{\circ} 49^{\prime} 677^{\prime \prime}$ \\
\hline I & Lecointe & Ind & & \\
\hline $\mathrm{Pt}$ & Neyt & Ind & $63^{\circ} 58^{\prime} 053^{\prime \prime}$ & $61^{\circ} 48^{\prime} 076^{\prime \prime}$ \\
\hline Rocks & Sophie & Ind & $64^{\circ} 14^{\prime}$ & $62^{\circ} 13^{\prime} 500^{\prime \prime}$ \\
\hline $\mathrm{I}, \mathrm{C}$ & Van Beneden & Ind & $64^{\circ} 46^{\prime} 067^{\prime \prime}$ & $62^{\circ} 42^{\prime} 308^{\prime \prime}$ \\
\hline Is & Wauwermans & Ind & $64^{\circ} 55^{\prime} 152^{\prime \prime}$ & $63^{\circ} 42^{\prime} 046^{\prime \prime}$ \\
\hline $\mathrm{I} / \mathrm{C}$ & Gerlache & Ind & $64^{\circ} 35^{\prime}$ & $64^{\circ} 15^{\prime}$ \\
\hline Str & de Gerlache & Ind $*+$ & & \\
\hline Str & Errera & Ind +$\}$ & & \\
\hline Str & Lemaire & Ind +$\}$ & & \\
\hline B & Leopold III & Ind & & \\
\hline B & Baudouin & Ind & & \\
\hline B & Pr. Elisabeth & Ind & & \\
\hline
\end{tabular}

$\mathrm{I}=$ island, $\mathrm{C}=$ cape, $\mathrm{Is}=$ group of islands, $\mathrm{Str}=$ strait or channel, $\mathrm{CP}=$ city or province in Belgium, $\mathrm{B}=$ base/station, Cst $=$ coast, $\mathrm{Pt}=$ point, DInd = individual who died during the expedition, Ind = individual.

* The Gerlache strait had been named Belgica Strait by de Gerlache.

$\dagger$ There is a Belgica Bank in the Arctic.

$\dagger$ Lemaire and Errera (Figure 1) are relatively common names in France and Belgium and it was neither possible to ascertain the identity of the individuals nor to determine whether the name was given during the Belgica expedition.

Belgica (now Gerlache) Strait (Figures 1, 5). Some descendants of the hapless sailor launched a claim on the island and resided there during the $1960 \mathrm{~s}$, but abandoned the isle after a few years. They are thought to have been inhabited by Karen and Scott Wiencke. The sub-Antarctic rocky island mostly covered by glaciers, snow, and ice, is surrounded by small islands such as Breakwater, Fridtjof, and the three volcanic Boby islands. During World War II, the German Navy used the waters of the Palmer Peninsula and the sub-Antarctic islands as a base wherefrom they attacked Allied shipping and Great Britain set up a base on Wiencke Island to counter the Germans. The second person to lose his life was Lieutenant Emile Danco, who succumbed to the effects of the cold and a weak heart. The island received a South American name as well, thus Danco Island is also Dedo Island. Furthermore, a coast segment has been named in his memory and current maps show a Danco Coast.

Among the Antwerp donors Ann Osterrieth rates a special recognition. She was part of a prominent family, with descendents later on active in aviation development, linked with the city business and the ancestral home, a "classed monument"4 that is still in existence on the Meir, a central

\footnotetext{
${ }^{4}$ A "classed monument" is under Belgian law a building that is considered part of the historical patrimony and that may not be altered, except for maintenance or repairs. It may nevertheless be held in use.
}

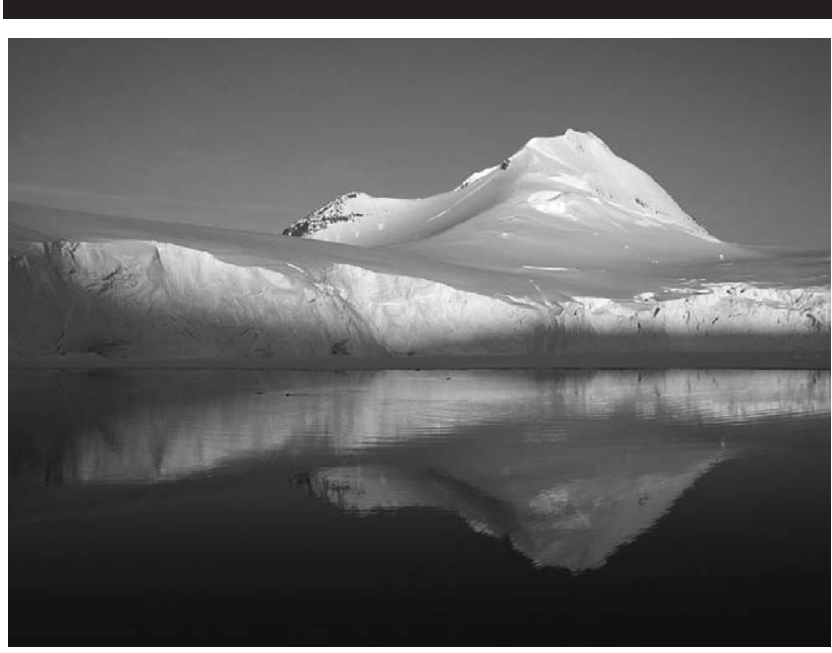

Figure 5. Sunset over Wiencke Island, December 2004. One of the photographs from the album of the Graham Peninsula-de Gerlache Strait.

artery of the mid-city. These authors attended secondary school with her family members. Thus Cape Ann is on the maps. de Gerlache did not neglect to think of his family and named Auguste Island after his father, and a group consisting of two others after his brother Gaston.

Van Beneden is a name closely linked with the biology department of the University of Liège; several members were at one time or another members of its faculty of sciences. An early member of that "academic" dynasty was involved with Antarctic science; no wonder that there is a Van Beneden Island.

Two generals' names have been immortalized: Lt. Gen. Henri E. Wauwermans, president of the Antwerp Royal Society of Geography, and General Neyt were both supporters of de Gerlache's plans. There is a group of Wauwermans Islands and a cape with that name; Neyt got his Point Neyt. The same name was bestowed on an Antarctic cape.

Unless we err, the British renamed in the 20thcentury the Belgica Strait Détroit de Gerlache (Gerlache Strait) (Figure 5); it snakes its way in between the islands that owe their names to the Belgica expedition.

Closer to the present "baptisms", there are the Belgica Mountains and the King Leopold and King Baudouin (Boudewijn, Baldwin) bases named after the fifth and sixth kings of the Belgians and now the Princess Elisabeth (daughter of Philippe, the current heir to the throne) station ensures a contemporary Belgian presence in the Antarctic (Figure 6). To top off this bird's eye view of Belgian names in the southern continent a spot is certainly due to Belgica antarctica, a flightless midge! The animal, at its size of from 2 to $6 \mathrm{~mm}$ is the largest terrestrial dweller of Antarctica. A prostigmatic mite Ereynetes macquariensis Fain, 1962 was collected at Bonaparte Point, Anvers Island, in 1972. Ereynetes macquariensis was first described ten years earlier by Fain from specimens collected on Macquarie Island.

But the ship went on further polar voyages and thus in 1905 when it plied Arctic waters and a heretofore undiscovered sandbank was located, the Belgica Bank was put on the map. 

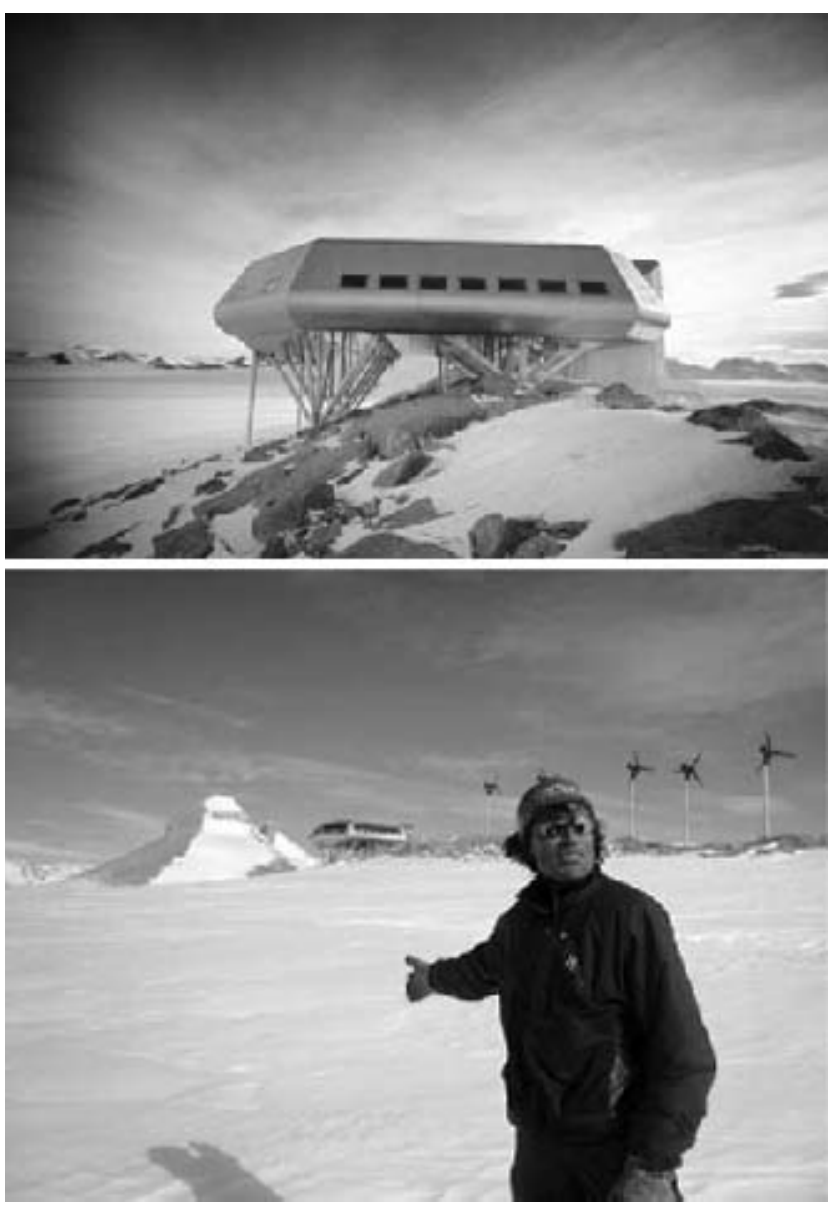

Figure 6. The Princess Elisabeth base on Antarctica.

The name of Gerlache Island (Figure 7) originates from the United Kingdom, but the site is also called De Gerlache Punta (Chile) and Gerlache Island (United States) and Gerlache isla (Argentina). A part of the Rosenthal Islands off the west coast of Ile d'Anvers, it is claimed by the United States, was charted by FAE (1903-05) as part of the main island and named Pointe

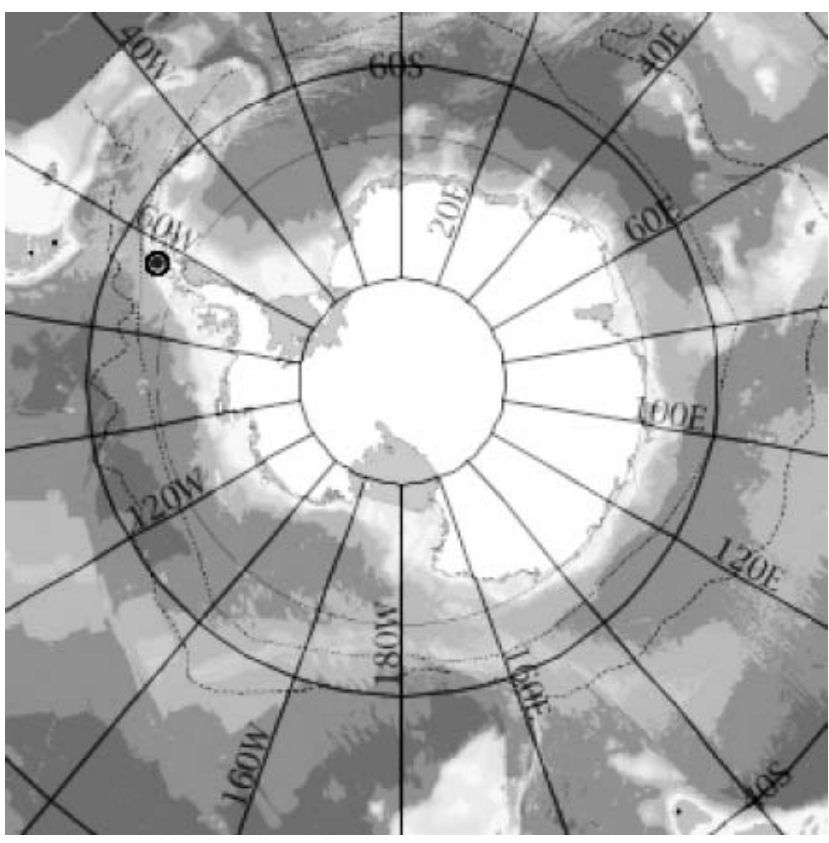

Figure 7. de Gerlache Island (U.S. claimed).

de Gerlache, evidently for Adrien de Gerlache de Gomery (the later Baron de Gerlache de Gomery) (1866-1933). Its geographical coordinates are $64^{\circ} 35^{\prime} \mathrm{S}$ and $64^{\circ} 15^{\prime} \mathrm{W}$.

One collaborator of de Gerlache on the expedition, Romanian biologist Racovița, convinced the captain to name an island for a compatriot and there is thus a Cobalcescu Island. Grigore Cobalcescu (1831-1892) was geologist and paleontologist, had been Racovitza's professor-occasionally hailed as "father" of most important Moldavian natural scientists-at Romania's first university, namely University "Alexandru I. Cuza" from Iassy (1860). There is also a (French Vice Admiral) Cuverville Island and De Gerlache also remembered an Argentinian scientist and politician and named Moreno Island for him. Harry Island and Cape Van Beneden owe their names to the expedition. They did not run out of islands to name on the Belgica, but either of deserving fellows, or worse, of time: winter was closing in!

\section{$\square$ RÉSUMÉ $\square$}

De Gerlache qui conduisit l'expédition de la Belgica il y a plus de cent ans dans l'Antarctique fut prolifique dans la collation de noms, le plus souvent belges, à des îles, caps et phénomènes géographiques, particulièrement dans le chenal qui porte aujourd'hui son nom. Il se fait de la sorte qu'en plus de personalités ainsi honorées, des villes et provinces belges qui apportèrent leur appui à son expédition furent immortalisées sur le continent le plus méridional.

\section{$\square$ SAMENVATTING $\square$}

De Gerlache die het bevel voerde over de ontdekkingsreis van de Belgica ,meer dan een eeuw geleden, gaf belgische namen aan talrijke eilanden en andere geografische fenomenen die hij ontdekte. Soms waren het namen van persoonlijkheden, soms van steden of provincies die hem steunde toen hij met zijn Antarctica project uitpakte. Dit gebeurde vooral in het nauwe dat heden zijn eigen naam draagt.

\section{$\square$ ZUSAMMENFAßUNG $\square$}

Während seiner wissenschaftlichen Expedition hat de Gerlache einige Inseln und geographische Eigentümlichkeiten entdeckt. Aus Dank für die erhaltene Hilfe bei der Lösung von finanziellen Schwierigkeiten bennante er viele davon nach belgischen Städten, Provinzen und Persönlichkeiten. Die Mehrheit sind in der Belgica z.Z. de Gerlache Meerenge gelegen. Der Artikel vertieft die Ortsnamen. 
Reproduced with permission of the copyright owner. Further reproduction prohibited without permission. 